\title{
Rehabilitation outcomes following autologous human stem cell transplantation in a chronic complete C4 tetraplegic - the first 12 months: A case report
}

\author{
Linda Elizabeth Hiemstra, B OT (SU), Dip Voc Rehab (UP) \\ Occupational Therapist, Back2Work
}

Liandi Terblanche, B.Sc Sports Science, B.Sc Hon Biokinetics, MSc Biokinetics, B.Sc Hon Cardiac
Physiology (North West University)

Biokineticist - Liandi Terblanche Biokinetics

Basil Adriaanse, B.Sc Physiotherapy (UWC)

Physiotherapist - Basil Adriaanse Physiotherapy

Autologous Human Stem Cell Transplantation (AHESC) is emerging as one of several promising new cell-based treatments for chronic spinal cord injury $(\mathrm{SCl})$. Since chronic $\mathrm{SCl}$ is generally deemed irreversible, treatment paradigms for post-intervention rehabilitation after many years of disability are limited, and a description of the impact of such intervention on the patients is hard to find. Here we describe, for the first time, the multi-disciplinary post-operative rehabilitation and outcome of a patient with chronic cervical SCl after autologous human embryonic stem cell transplant. We include the anatomical, physiological, functional and quality of life outcomes. Methods: A 33 year old male, American Spinal cord Injury Association (ASIA) Grade A, C4 chronic SCI patient received glial scar resection and Autologous Human Embryonic Stem Cell (AHESC) transplant, 6 years after injury, and thereafter had intensive interdisciplinary rehabilitation comprising occupational, biokinetic and physiotherapy, for an average of 17 hours per week over the course of 12 months. Outcomes were measured with standardised outcome measures of physiological improvement, increased independence, and a questionnaire was designed to gain understanding of the changes in quality of life and well-being of the patient, from his perspective. Results: The patient progressed from ASIA Grade A to ASIA Grade C, over the first I 2 post-operative months. Sensory recovery comprised awareness of deep pressure and light touch in all dermatomes, with accurate localisation to LI. Motor activation was restored to all major muscle groups of the right upper limb, and to a lesser extent in the left upper limb, with some recovery in thoracic, abdominal and spinal muscles. Gains have been made in areas of motor, sensory and vascular function, self-care, wheelchair use and safety, and leisure participation. The patient has found these changes meaningful in terms of quality of life.

Conclusion: Regenerative medicine approaches may create rehabilitation potential where none formerly existed, presenting unprecedented challenges to rehabilitation therapists. Our experience demonstrates the value of intensive multi-disciplinary rehabilitation programmes in this setting, and provides a template for functional restoration and retraining after many years of chronic disability. It also emphasises the need to debate the ethical questions surrounding the application of such interventions and highlights the impact that participation in rehabilitation can have on a patient's perception of quality of life and health status.

Key words: Human therapeutic cloning, autologous human embryonic stem cells, spinal cord, spinal cord injury, quadriplegia, motor rehabilitation, motor retraining, mirror therapy, quality of life

* Louis is a pseudonym, used to protect the patient's identity.

\section{INTRODUCTION:}

Cervical spine injuries often result in serious disability, including paraplegia, tetraplegia and complete paralysis. Although acute spinal cord compression is potentially reversible with emergency decompression, recovery may be incomplete. Partial or complete spinal cord transection leads to permanent neurological damage. The level of the injury and the degree of spinal cord compromise determine the extent of the impairment ${ }^{1,2}$. The severity of the disability is further influenced by external factors, which may be environmental and contextual. These include aspects such as social attitudes, home environment, political and social policies, and access to community resources. Internal personal factors such as age, gender, education level, mental health, previous experience and behaviour, and coping styles of the individual also play a part in facilitating or preventing participation. Disability as a result of a spinal cord injury can be viewed as the outcome of the interaction between the health condition and these contextual factors ${ }^{3}$.

Multidisciplinary rehabilitation of persons with spinal cord injury can aid recovery and improve outcomes. Up to now the severity of the injury has been one of the main determinants of prognosis, particularly from a medical point of view. Those with complete injuries have a poor chance of improvement ${ }^{4}$. In the event that motor and sensory improvement does occur, this happens largely within the first 6 months and continued improvement beyond 18 months is rare ${ }^{5-7}$. In-patient rehabilitation generally occurs during the first two to six months after injury and outpatient rehabilitation is seldom provided beyond 12 months s $^{5,8-15}$

Typically, the therapeutic approach to the management and re- 
habilitation of persons with spinal cord injury focuses on functional restoration by maximising residual motor function and returning neurological activity, or on overcoming losses with compensatory techniques and the use of assistive or adaptive devices and equipment $\mathrm{t}^{4,8-10}$. Intervention is generally planned based on the patient's level of injury and specific prognostic predictors of expected outcome, such as pre-injury level of function, home environment, education level, pre-injury life roles and tasks, and the future plans of the patient. The goal of rehabilitation is to facilitate safe discharge to an appropriate environment, and enable optimum performance in self-care, productivity and leisure participation ${ }^{6}$. However, in South Africa, rehabilitation is limited by funding and pressure on bed occupancy. Patients with private medical aid are eligible for funding for two months of inpatient rehabilitation under prescribed minimum benefit legislation ${ }^{16}$, while in the public sector, in-patient therapy is limited to approximately six to twelve weeks (Personal communication, Bed manager WCRC, I I/2/I5). Patients are therefore reliant on their own resources for further therapy after discharge, but communication from medical professionals to patients with spinal cord injuries, specifically those with complete injuries, often implies that no functional gains are expected, and few seek further rehabilitation. As a result of these and other barriers, very few patients with complete lesions receive any rehabilitation in the sub-acute or chronic phase $\mathrm{e}^{\mathrm{Il-13}}$.

Recent advances in regenerative medicine and therapeutic cloning may have the capacity to change this, as the promise exists of interventions that could restore function to organs and structures previously deemed irrevocably damaged ${ }^{4,17-18}$. For spinal cord injuries, this has meant the prospect of improvement in, or restoration of, neurological function, despite injuries which previously resulted in catastrophic and irreversible disability ${ }^{19-20}$. One such development is the use of stem cell transplantation, which has shown promise in many animal and human models ${ }^{20-28}$. This could dramatically change the landscape of post spinal cord injury rehabilitation, as suddenly, persons who previously had no prospect for recovery, may have the potential to improve.

In this paper we present our approach to, and outcomes of the post-operative rehabilitation of a chronic complete $\mathrm{C} 4$ quadriplegic patient following $\mathrm{C} 4 / 5$ glial scar resection and autologous human embryonic stem cell (AHESC) transplantation, 72 months after injury. We report interventions, schedules, outcome assessments and functional improvement, over the first 12 months post transplantation.

\section{METHODS}

Quantitative data were collected making use of physiological assessments (electromyography, testing of cardiac and respiratory function, and assessment of muscle strength, sensation and range of movement) pre-transplant, in preparation for surgery and rehabilitation, and repeated 12 months later in order to compare results. Specific outcome measures (American Spinal cord Injury Association scale $[\mathrm{ASIA}]^{29}$, Landrum outcome levels ${ }^{30-31}$, Loewenstein Spinal Cord Independence Measure, Third Edition [SCIM-III] ${ }^{32}$ ) were selected to measure changes to motor and sensory function and independence in various aspects of activities of daily living.

The ASIA scale uses a multi-dimensional approach to categorise motor and sensory impairment in individuals with spinal cord injury, and classifies patients from grade $A$ (complete spinal cord injury) to grade $E$ (normal motor and sensory function) ${ }^{29}$. It provides an internationally accepted system to classify the severity and extent of impairment as a result of a spinal cord injury, and is sensitive to changes in sensory and motor function.

To ensure a continuum of care, the outcome levels suggested by Landrum et $\mathrm{al}^{30,31}$ which had been used at the rehabilitation facility where the patient was initially treated following his injury, were used thereby providing an excellent basis for comparison with our own rehabilitation. These six levels of outcome (see Table I) would also allow us to measure the impact of rehabilitation on the extent and quality of our patient's participation in the different domains.
Table I: Levels of outcome in rehabilitation. Landrum et al. (1995)

\begin{tabular}{|c|l|l|}
\hline 0 & $\begin{array}{l}\text { Physiologic } \\
\text { Instability }\end{array}$ & $\begin{array}{l}\text { Immediately after onset of injury or illness } \\
\text { when there are unmanaged medical } \\
\text { diagnostic and management problems } \\
\text { which need care in an acute care setting. }\end{array}$ \\
\hline I & $\begin{array}{l}\text { Physiologic } \\
\text { stability }\end{array}$ & $\begin{array}{l}\text { First and most basic outcome level, all } \\
\text { major medical and physiological problems } \\
\text { addressed and appropriately managed. }\end{array}$ \\
\hline 2 & $\begin{array}{l}\text { Physiologic } \\
\text { maintenance }\end{array}$ & $\begin{array}{l}\text { The achievement of preservation of } \\
\text { immediate and long-term physiologic } \\
\text { health. }\end{array}$ \\
\hline 3 & $\begin{array}{l}\text { Residential } \\
\text { reintegration }\end{array}$ & $\begin{array}{l}\text { Achievement of proficiency in self-care, } \\
\text { mobility, communication, safety and home } \\
\text { management to function in a residential } \\
\text { setting. }\end{array}$ \\
\hline 4 & $\begin{array}{l}\text { Community } \\
\text { reintegration }\end{array}$ & $\begin{array}{l}\text { Achievement of an appropriate level of } \\
\text { function within the community. Includes } \\
\text { self-management, social competencies, } \\
\text { community mobility, complex home- } \\
\text { making capabilities, financial management, } \\
\text { self-directed health monitoring and } \\
\text { recreation. }\end{array}$ \\
\hline 5 & $\begin{array}{l}\text { Establishment of the individual in } \\
\text { productive activities within his/her } \\
\text { capacity. May involve vocational, } \\
\text { avocational or educational pursuits. }\end{array}$ \\
\hline activity & &
\end{tabular}

The Loewenstein Spinal Cord Independence Measure (SCIMIII) ${ }^{32}$ was also used to measure gains in independence. This measure was developed specifically for persons with spinal cord injuries, to make the assessments of these patients more sensitive to change. It includes the following aspects: Self-care, respiration, sphincter management and mobility.

Qualitative data regarding the patient's experience of rehabilitation and his resultant changing abilities were also collected. The aim was to encapsulate his perception of the impact of the surgery and rehabilitation on his quality of life in general.

Various quality of life questionnaires were reviewed in an attempt to find a tool which would provide rich data regarding the patient's experience of the changes brought about by the transplant, but none were felt to be sufficiently detailed. A new questionnaire was therefore drawn up, containing twelve questions which were derived from selected items contained in the Quality of Life Index, Spinal Cord Injury Version (QLI-SCI ${ }^{33}$, specific aspects of function identified as significant in the Loewenstein SCIM-III, and aspects that had been identified by the patient as being significant during personal communication. The aspects that the patient identified as significant included the impact of the implant and subsequent rehabilitation on his family and friends, the financial impact, changes to general health and the socio-emotional impact in his own life. Specific questions were included to assess these factors and particular components of his recovery, such as sensory and motor function, and bowel and bladder control. The questionnaire was administered as a formal interview and responses were recorded and transcribed.

\section{Informed consent and ethical considerations}

Our patient had participated in an exhaustive process of providing informed consent prior to the surgery, which included consent to participate in rehabilitation. Consent was obtained verbally and documented on video, as well as in writing, with the patient providing a thumb-print in lieu of a signature. The ethical aspects of the surgery were reviewed by the hospital ethics committee and all permissions that had been obtained from various regulatory bodies were accepted.

In terms of informed consent for this article, the purpose and scope of the article was discussed with the patient, who subse- 
quently provided verbal consent. All of the findings discussed in this article were discussed with the patient prior to commencement of writing and the ethical principles of beneficence, non-maleficence, and respect for autonomy were upheld throughout the course of his rehabilitation and the writing of this article.

\section{THE CASE}

\section{Pre-injury}

Prior to his injury, our patient, Louis* was a healthy, independent 25 year old Caucasian male, the younger of two siblings. After completing his high school education, he went abroad, returning after four years. Initially, he lived with his parents on the family farm in an Overberg farming community, but he had plans to move to Hermanus where he was due to start working at, and later become a partner in, a privately owned marble- and granite manufacturing business.

\section{Injury and acute management (March - May 2006)}

Louis sustained a bilateral C4/5 vertebral facet dislocation in a diving accident in March 2006, resulting in complete C4 motor and sensory tetraplegia, American Spinal Injury Association (ASIA) Grade A (No sensory or motor function below the level of the injury). Initial acute management included mechanical ventilation and a C4-5 anterior discectomy and fusion. He was discharged from the acute surgical unit after 7 weeks, to a high intensity rehabilitation facility. He had an indwelling catheter and had started a bowel management programme. At this time Louis still had complete C4 motor and sensory tetraplegia and an ASIA score of 28/ I I4.

\section{Initial rehabilitation (June-August 2006)}

Rehabilitation was limited to the provision of a suitable motorised wheelchair and training on its use, psychological support, the provision of devices to enable independent communication with his mobile telephone, bowel and bladder management, family education and training, and discharge planning. Upon discharge from this facility after twelve weeks of rehabilitation, motor function below the level of C4 was absent with the exception of (Oxford scale grade) I/5 power in right external shoulder rotators (C5) and right elbow flexors (C5) (zone of partial preservation). Mobility was only possible with the use of a chin control on the motorised chair. On discharge, he had reportedly achieved Landrum's outcome level III (Residential re-integration).

Assessment by specialists at the initial acute management facility fourteen months after injury found no further neurological recovery and, given the absence of further functional gains, he was not offered further rehabilitation.

\section{Post-injury recovery and adaptation (September 2006 - August 2012)}

Louis was discharged from the rehabilitation facility to a group home for wheelchair users, as returning to his family home in a local farming community was deemed impractical. He still had regular contact with his parents, sister, and friends, who came to visit regularly and kept in touch telephonically. On arrival at the group home, his endurance was so poor that he was unable to spend much time out of bed. As this improved, he started participating in activities presented at the home on a more regular basis, and began socialising with other residents. Following the initial adaptation to his new circumstances and new home environment, Louis started becoming depressed as a result of the losses he experienced. His parents assisted with accessing psychotherapeutic services and he was referred to psychiatry for pharmacological support.

Over time, (2006-20I2) Louis adapted to his new circumstances and his mood stabilised. He progressed to Landrum's outcome level IV (Achievement of an appropriate level of function in the community, including social competencies, community mobility, self-directed health monitoring and participation in leisure tasks) ${ }^{30,31}$.
With support from his family and friends, he was able to purchase a converted mini-bus, and portable ramp, which provided more freedom to engage in social activities and go on outings. Participation was still limited by the need for a driver and assistance to remain upright in his chair while travelling in the minibus. He purchased a variable air-mattress to aid with pressure care, and had a wheelchair imported which was better suited to his particular needs, to replace the one issued on discharge from the inpatient facility. He obtained a mouth-control for his laptop computer and a family member built a control panel for the light switch, call button and television remote, so that he could control his environment to some extent.

He also enrolled in formal studies through a distance learning university in order to obtain a qualification which would be of benefit in the business world, as he remained a partner in the business where he would have commenced employment, but for his injury. Louis and his family started researching alternative treatment options which could lead to improved independence.

Over the course of the next thirty-six months, Louis had no therapy. Physically, he regained partial function of shoulder girdle muscles on the right, specifically partial function of the middle fibres of deltoid (Oxford scale Grade 2+/5), upper trapezius (Oxford scale Grade 4/5), and flickers in biceps. These muscles are all innervated to some extent by $\mathrm{C} 4$ or $\mathrm{C} 5$, confirming the zone of partial preservation. On the left, he used upper trapezius fibres to achieve a degree of shoulder movement but this was not functional. Secondary complications such as severe extensor spasms, pressure ulcers on both ankles, frequent urinary tract infections and pneumonia, impacted his capacity to take part in productive and social activities.

Forty-six months after discharge from the acute hospital where he was initially treated and medically stabilised, Louis sought rehabilitation from an independent, private facility. Treatment was provided over a period of three months, consisting of 60-minute sessions with a student biokineticist twice weekly. These sessions included training on an active-passive upper limb trainer, and passive-assisted weight training using a pulley system. Passive movement of joints was carried out to maintain range of motion and prevent secondary complications such as contractures. Although strengthening of the right shoulder girdle and right biceps was documented, no real functional gains were made, and no additional neurological recovery occurred. Strengthening therefore only occurred in myotomes with pre-existing function. Rehabilitation was stopped as a result of transport difficulties and costs involved. He also required skin grafts to repair defects caused by pressure ulcers on both ankles, and bed rest was recommended for six months.

\section{Pre-transplant assessment and surgical procedure}

Seventy-eight months after injury, Louis sought a neurosurgical opinion regarding AHESC transplantation from a private neurosurgeon. He had read much on the subject and was prepared to travel wherever necessary to obtain the appropriate treatment. A series of events and circumstances, which fall outside the scope of this article, had brought him to the conclusion that regenerative therapy was the treatment of choice for patients with SCl. Although he had come to terms with his disability and had adapted to his impairments effectively, he demonstrated a keen interest in scientific progress and expressed a desire to participate in the process of medical innovation. He was identified as a potential candidate for an open surgical transplant due to the nature and chronicity of his injury.

Further conversations with Louis, revealed a young man who had already come a long way since his injury. Carl Rogers ${ }^{34}$ stated in his discussion on the theory of creativity that man has a tendency to become his potentiality, but that there are certain conditions inherent to the person required in order to reach this full potential. These include openness to experiences, an internal source of the value of what is being created, and an ability to play with ideas. This theory frames Louis perfectly. He was willing to accept the risks inherent to a procedure that had never been done before and had 
no guarantee of success. He felt that he had a role to play in the advancement of medical knowledge and had sufficient courage to accept the unknown. Although not entirely accurate, his expectations regarding his possible recovery and progress in rehabilitation were deemed to be realistic and well grounded. His support structure, frame of reference and realistic expectations further added to his suitability for this procedure.

A pre-transplantation MRI scan demonstrated a discontinuous spinal cord with a $33 \mathrm{~mm}$ defect. Clinical assessment by the neurosurgeon confirmed a sensory level at C4 with complete loss of all sensory modalities below this level. Motor examination demonstrated (Oxford scale grade) 2/5 muscle strength for right shoulder abduction (C5) and (Oxford scale grade) $3 / 5$ muscle strength for right biceps (C5), but all motor function below the level of $\mathrm{C} 4$ on the left was absent.

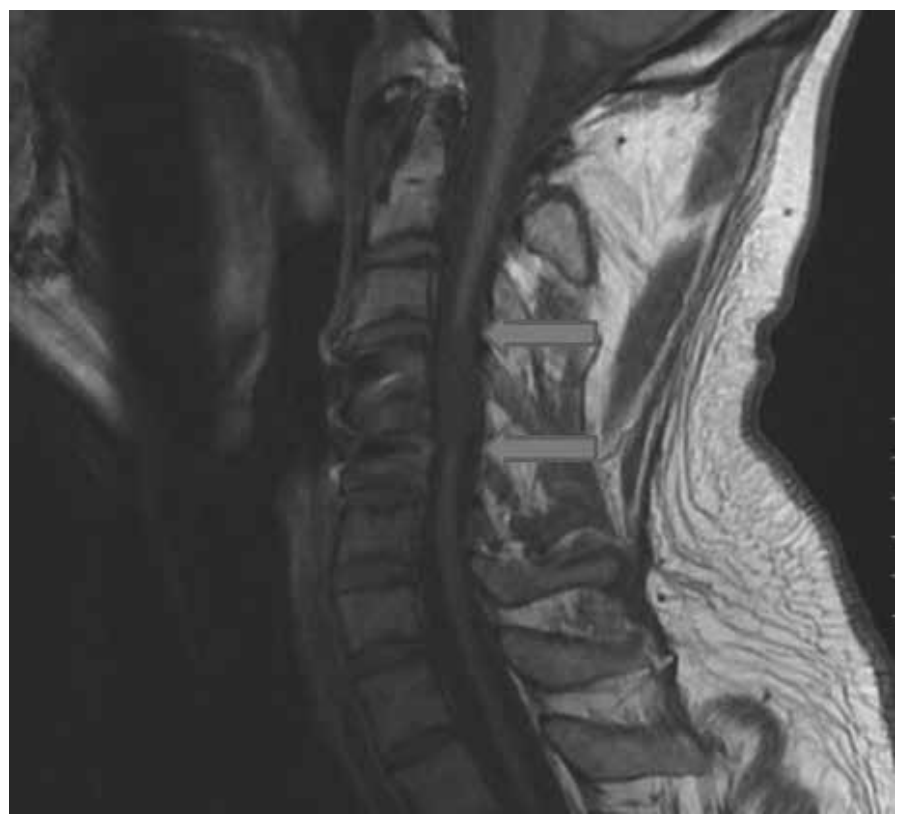

Figure I: Baseline pre-surgical MRI scan demonstrating

$33 \mathrm{~mm}$ section of scar tissue causing complete interruption of spinal cord

Autologous human embryonic stem cell transplantation was subsequently carried out as a two-stage open surgical procedure in October 2012, as previously reported ${ }^{21}$. After the $5^{\text {th }}$ post-operative day, an independent neurosurgical assessment confirmed complete C4/5 motor and sensory quadriplegia, with no functioning below the level of C5. Louis was referred for rehabilitation.

\section{Post-transplant rehabilitation (October 2012 - October 2013)}

\section{Theoretical framework}

A search of Pubmed and Occupational Therapy specific databases (OTSeeker, OTCATS) revealed multiple studies on stem cell research, animal studies, application of adult stem cells in humans, and rehabilitation of $\mathrm{SCl}$ but in general, but minimal literature applicable to rehabilitation protocols, expected outcomes, or previously successful treatment strategies for patients who had received this specific surgical and cell-based intervention ${ }^{25-26}$. We therefore designed our own individualised, intensive interdisciplinary rehabilitation programme, aimed at facilitating any recovery that might occur.

Fundamental principles of our approach included the pooling of expertise from occupational therapists, physiotherapists and biokineticists, resulting in a comprehensive, seamless rehabilitation strategy without the compartmentalisation that commonly occurs in conventional settings ${ }^{8-9}$. The aim was to create an interdisciplinary team that could provide rehabilitation across disciplines. Due to the intensity of intervention envisaged, each therapist had to be able to assume the functions and responsibilities of every other. The above-mentioned disciplines were combined into treatment pairs which changed daily. This ensured a holistic, multi-faceted perspective, and team meetings were held on a weekly basis to identify rehabilitation goals and review progress.

As the literature available to guide us was limited with regards to detailed descriptions of the content of rehabilitation, our approach had to be underpinned by physiological, anatomical and developmental principles, as well as the therapeutic principles inherent to the three disciplines. Our treatment plans rested on the following assumptions: I) Recovery would follow a descending pattern, with recovery of one spinal segment leading to recovery of the next segment, 2) that large, proximal muscle groups would recover more rapidly than smaller, more distal muscle groups, 3 ) sensory and motor return would be mutually conducive and 4) recovering neural pathways would require maximal repetition to ensure maturation and sustainability. The above assumptions, and the combined knowledge and experience of the clinicians involved, led to the design of a custom-made rehabilitation programme.

Louis had been living with his disability for six years and seven months prior to the transplant. We assumed that he had optimised his environment and context to enable and maximise activity participation and performance despite impairment of body functions and structures. Therapy after the transplant would have to target these impairments that had previously been accommodated by the use of personal assistance or assistive devices. The aim would be to reduce impairments of body functions and structures that had previously been assumed to be static, with the goal of achieving improved activity participation in all realms of life.

With this in mind, we set out to identify goals and aims of therapy, roles and responsibilities for the various therapists involved, and to identify a starting point. Initially, in the acute and sub-acute phase, physiotherapy and occupational therapy were envisaged to be the lead clinicians, with biokinetics becoming essential as motor function returned and muscle imbalances were identified.

In designing the rehabilitation programme, we employed interventions with evidence of efficacy in the conventional model of early rehabilitation post-spinal cord injury, and post-stroke rehabilitation, such as neuro-muscular treatment techniques, performance-based intervention and repetition of tasks to stimulate patterned neuronal activity ${ }^{5-9,15,23}$. Decisions regarding therapy techniques and tasks were also influenced by availability of equipment, cost to the patient, space, and the likely impact that participation in rehabilitation would have on his pre-existing participation in tasks and activities, lifestyle, relationships and role performance.

Task selection and decisions regarding intensity of therapy were based on the evidence that suggests that patterned neuronal activity is important in the developmental processes of normal CNS, including cell birth, migration, differentiation and the selection of new circuits. Research suggests that task-based interventions and patterned neuronal activity may have an impact on a patient's physical condition and has the potential to facilitate functional recovery ${ }^{7}$. Repetition of tasks would also be a key element, as other studies showed that intensity of rehabilitation varied between 25 and 39 hours per week ${ }^{7,24-26}$. Tasks and movements were therefore selected based on patterns of normal human development, and the assumption that repetition of the said patterns would be required to achieve activation and regeneration of neural and muscular structures, which in turn would facilitate activity participation and performance.

Literature regarding central and spinal cord cortical re-organisation guided selection of treatment techniques, which included motor retraining, graded motor imagery and mirror therapy ${ }^{35-43}$ Particular attention was paid to the use of left-right discrimination, imagined movements and mirroring to stimulate the sensory and motor cortices. The sensory and motor cortex in patients with spinal cord injury reorganises rapidly after injury, with enhanced representation of the uninjured parts of the body in the cerebral cortices, and exaggerated responsiveness of the spinal nerves after 
injury. This could explain the presence of neuropathic pain and even phantom sensations ${ }^{44-46}$. Moseley and Flor ${ }^{47}$, in their discussion on theories surrounding the treatment of phantom limb pain, state that the brain responds to the perceived reality as much, if not more than, to the actual reality. For this reason, observing an existing, normal limb in a mirror, can reduce pain in the phantom limb as a result of cortical re-organisation.

We postulated that similar techniques might be beneficial in Louis' treatment. We reasoned that it was likely that passive movement, sensory stimulation of the area to be moved, observing someone else performing the movement and imagining doing the movement, would help to re-organise the cortical representation of a body part and activate pathways that previously existed but had been dormant for many years. In practice, this approach seems to have been the most useful when attempting to enable relearning of previously automatic movements.

\section{Phases of rehabilitation}

Rehabilitation aims during the acute post-transplantation phase focused on treatment of changing body systems and structures with a view to improving capacity for task performance, particularly in the areas of self-care, bed-mobility and leisure participation. Immediately post-discharge, therapy was aimed at achieving Level 2 (Physiologic maintenance) outcomes while Louis was an inpatient. Although he had achieved Level 4 outcomes as an out-patient between 2006 and 2012, our aim was to increase his repertoire of tasks and increase his independence in the performance of these tasks. Rehabilitation of specific components of function was required as precursors for participation in real-life tasks, but the entire rehabilitation approach had to be framed in terms of improving performance and capacity of activity participation, and improved quality of life.

Rehabilitation began at the point of referral. Initially, our assessment focused on physical components of function. The first assessment was done 5 days post-transplantation and clinically confirmed C4/5 complete tetraplegia, ASIA score 29/I I 4 (Grade A).

Motor function was restricted to right shoulder elevation (Oxford scale grade $2+/ 5$ ) and abduction (Oxford scale grade $2 / 5$ ), and elbow flexion (Oxford scale grade 2+/5), (C5); and on the left, shoulder elevation only. There was complete sensory loss below the level of C4.

Functionally, Louis' status was similar to his capacity prior to admission. He was fully dependent for all aspects of care, and arrangements had been made to allow his regular care-giver to stay in hospital for the duration of his admission. Psychosocial assessment was deferred until he was deemed medically and physiologically stable.

Rehabilitation during the first 12 months post-operatively was divided into three phases, based on the key focus of intervention, namely: I) Acute and sub-acute post-operative management; 2) cardiovascular and motor retraining; and 3) functional retraining, with phases 2 and 3 containing overlapping components.

Phase I (week I - I6): Initial acute post-transplant rehabilitation focused on similar aspects of treatment to those expected for persons with $\mathrm{SCl}$ immediately post-injury, namely respiratory management and maintenance of joint range of motion and flexibility. In this case, neuro-muscular rehabilitation and sensory stimulation techniques normally used in stroke rehabilitation ${ }^{38-40}$ were added, with particular attention being given to improving the tone and muscle responses in both upper limbs. Stimulation techniques, such as sweeping, tapping, ice, and electrical stimulation were applied mainly to muscles in the C5-TI myotomal distribution, as a descending pattern of recovery was anticipated. Graded motor imagery techniques such as left-right discrimination, and imagined movements were added. Flash cards, computer based programs, and observation of active movements, were used as part of a graded motor imagery regime. Principles of mirror therapy were used to achieve activation of forearm and hand muscles, but traditional techniques had to be adapted to match Louis' capacity.
Because he did not have a functional limb which could be observed in a mirror, the therapist made use of her own limbs, which Louis observed while attempting to perform the task. Physiological changes such as increased temperature and sweating were noticed in his limbs, and muscle flickers were observed in response to attempts at movement. Active assisted movement was initiated as soon as a muscle response was noticed in previously inactive muscles. Passive-assisted movement of inactive muscles was used to establish activation through afferent feedback.

Treatment consisted of four 60-minute sessions daily, 7 days per week for the first four months.

Phase 2 (week 17 - 40) was introduced when Louis developed improved diaphragmatic and intercostal activity, leading to improved respiratory function. He also reported sensory feedback from dermatomes corresponding to thoracic and upper abdominal muscles, raising the possibility of recovery of function of trunk musculature.

At the start of this phase, physiological stability had been achieved. Louis started participating in goal setting. He identified improved safety and confidence with wheelchair mobility as one of his goals. This involved being able to drive his chair for longer distances without assistance, driving up and down inclines safely, being able to remove the side supports, leg straps and head support from the wheelchair and being confident when driving the wheelchair over uneven terrain, as this would allow him to participate in more social outings. He also wanted to progress to a manual wheelchair eventually. Louis also wanted to be able to participate in some self-care tasks, such as feeding himself, being able to roll in bed and have improved sitting balance in his shower chair. In terms of leisure activities, he identified using his hands for the independent operation of his mobile phone (making calls, sending texts and playing music/games) as one of his main goals.

The focus was on activation of trunk muscles, improvement of posture both in and out of the wheelchair and achieving independent balance without external support when sitting in a wheelchair. Louis had previously relied on external trunk supports and straps, to maintain his position in the chair. Achieving independent balance to the extent that the external supports could be removed was a major accomplishment, and was important for the improvement of his self-confidence and self-esteem. Tasks related to bed mobility, upper limb use and balance, were added as recovery progressed. These included rolling from supine to side-lying, weight bearing through the upper limbs in preparation for transfers and pushing up onto the elbows from supine or prone, and practising movements required for independent feeding and operation of wheelchair controls.

Emphasis was also placed on improving his cardiovascular function and overall endurance, as well as strengthening his shoulder girdle and trunk musculature on the premise that shoulder and trunk stability is required for distal mobility during hand function. Treatment during this phase included upper limb strengthening on an active/passive trainer, voluntary core activation while sitting without support, posture and balance re-training and hydrotherapy.

Development of sensation in the lower thoracic and upper lumbar dermatomes prompted us to incorporate passive-assisted pelvis and hip movement. Subsequent flickers of movement in inferior sections of erector spinae, external and internal obliquus, lattisimus dorsi and gluteus medius led to the decision to add active-assisted movements which would require the use of these muscles.

During Phase I and 2, Louis had to adjust to changing function of body systems and structures, which challenged his accepted view of his capacity and capabilities. Dubouloz et $\mathrm{al}^{48}$ describe the process of personal change which occurred in patients with rheumatoid arthritis as a result of their participation in Occupational Therapy, and the threats to an individual's core values, beliefs and feelings as a result of a focus on occupation performance modification in treatment. In this case, Louis experienced similar threats, as the focus was also on occupation performance modification, but here, adaptation was required as a result of recovery, rather than disease progression. As no comparative case was available at the time of 
the transplant, Louis' expectations of how recovery would occur was based on anecdotal reports and information provided in the popular media regarding the regenerative properties of stem cells. One of the first and most important challenges to his beliefs was that recovery would not occur spontaneously, merely as a result of the transplant, but would require intensive rehabilitation and active participation.

Every aspect of returning function presented a challenge to his belief system and knowledge of his previous capabilities. Prior to the transplant, his belief was that he was unable to do anything independently, and he would wait for assistance. During rehabilitation, he would always be asked to try something independently before assistance would be offered. Many a true word is spoken in jest, and Louis would often jokingly ask: "Must I do everything myself these days?". The time and effort required to re-learn movements and co-ordinate muscle action surprised him, and often caused frustration and occasional despair. It was essential for the therapists to provide continuous feedback and contextualise progress in order to keep him motivated. The occupational therapist in particular, had to assist him with a process of adapting to the possibility of performing tasks independently which had previously been impossible and much time was spent preparing him emotionally for new exercises, or progression to greater independent participation in a particular task, before treatment goals were set and therapy progressed to the next phase. The development of self-confidence and a revised frame of reference was an essential part of rehabilitation and was often the key to the achievement of a particular goal.

After approximately 8 months of therapy, Louis expressed a readiness to attempt more real-life activities, such as active participation in bed mobility, feeding and recreational activities, such as using his mobile phone and computer to play games and access entertainment; go on group outings to restaurants, attend concerts, and participate in team building activities with other residents in

Table II: Rehabilitation schedule for first 56 weeks following AHESC transplantation

\begin{tabular}{|c|c|c|}
\hline $\begin{array}{l}\text { Rehabilitation } \\
\text { phase }\end{array}$ & Weeks & Content \\
\hline \multirow[t]{3}{*}{ Phase I } & I-4 & $\begin{array}{l}\text { 3-4 } \times 45-60 \text { minute sessions daily, } 7 \text { days/week. } \\
\text { Acute and subacute post-operative management. } \\
\text { Session I: Passive ranging of all joints, respiratory management and deep breathing exercises. } \\
\text { Session 2/3: Sensory and motor stimulation of right upper limb using joint compression, deep pressure, sweeping, } \\
\text { tapping, ice, electrical stimulation. } \\
\text { Imagined movements, right/left discrimination, active assisted/passive assisted movement. } \\
\text { Session 4: Passive ranging of all joints, respiratory management/deep breathing exercises. }\end{array}$ \\
\hline & $5-6$ & $\begin{array}{l}4 \times 60 \text { minute sessions daily, 6-7 days/week. } \\
\text { Session I: Passive ranging of all joints, respiratory management and deep breathing exercises. } \\
\text { Session 2: Right upper limb: sensory and motor stimulation using joint compression, deep pressure, sweeping, } \\
\text { tapping, ice, electrical stimulation. } \\
\text { Imagined movements, right/left discrimination, active assisted/passive assisted movement. } \\
\text { Session 3: Left upper limb: Sensory and motor stimulation using joint compression, deep pressure, sweeping, } \\
\text { tapping, ice, electrical stimulation. } \\
\text { Imagined movements, right/left discrimination, active assisted/passive assisted movement. } \\
\text { Respond to new signs of movement or sensation as these occurred by stimulating new function with attempted } \\
\text { active assisted movement, imagined movement. } \\
\text { Session 4: Passive ranging of all joints, respiratory management and deep breathing exercises. }\end{array}$ \\
\hline & $7-16$ & $\begin{array}{l}\text { Session } 2 \text { or } 3 \text { replaced by session to stimulate abdominal muscles, as sensory feedback from abdominal and } \\
\text { spinal muscles reported by patient initially in Week } 7 \text {. } \\
\text { Pt sitting on edge of bed with support - decrease postural hypotension by positional changes, achieve weight- } \\
\text { bearing through spine, attempt activation of core musculature. }\end{array}$ \\
\hline \multirow[t]{3}{*}{$\begin{array}{l}\text { Phase } 2 \\
\text { Cardiovascular } \\
\text { and motor } \\
\text { retraining }\end{array}$} & $17-20$ & $\begin{array}{l}3 \times 60 \text { minute sessions, } 3 \text { days/week. } \\
\text { Session I: Upper limb stimulation and training as described above. Strengthening of pre-existing and emerging } \\
\text { muscle activity. } \\
\text { Session } 2 \text { and 3: Core activation, balance re-training, postural re-training to correct spinal and pelvic alignment. }\end{array}$ \\
\hline & $21-24$ & $\begin{array}{l}3 \times 60 \text { minute sessions, } 5 \text { days/week. } \\
\text { Programme as for weeks } 17-20 \text { above, but with additional upper limb training on active/passive trainer twice } \\
\text { weekly, one additional session working on stimulation of function in upper limb function, two sessions daily to } \\
\text { strengthen core musculature and achieve voluntary muscle activity in descending order. }\end{array}$ \\
\hline & $24-40$ & $\begin{array}{l}3 \times 60 \text { minute sessions, } 4 \text { days/week. } \\
4 \times 60 \text { minute sessions, I day/week. } \\
\text { Hydrotherapy once per month - } 45 \text { minute session incorporating upper limb and core training. } \\
\text { Session I: Upper limb stimulation and training. } \\
\text { Session 2: Upper limb training on active/passive trainer. } \\
\text { Session 3: Core training/balance re-training/postural retraining. } \\
\text { Session 4: Mat-work, postural/balance training using therapy ball. }\end{array}$ \\
\hline $\begin{array}{l}\text { Phase } 3 \\
\text { Translating } \\
\text { neurological and } \\
\text { motor gains to } \\
\text { function }\end{array}$ & $4 I-56$ & $\begin{array}{l}3 \times 60 \text { minute sessions, } 3 \text { days/week for week } 4 \mathrm{I}-50 \text {, increased to } 4 \times 60 \text { minute sessions, } 4 \text { days/week. } \\
\text { Aims of intervention changed to incorporate preparation for independent transfers, bed mobility, feeding. } \\
\text { Session I: Upper limb stimulation and training, use of assistive device for independent feeding. } \\
\text { Session 2: Upper limb training on active/passive trainer. } \\
\text { Session 3: Core/balance retraining, weight-bearing and weight shift through upper limbs in sitting, active trunk } \\
\text { rotation, active flexion/extension of trunk using upper limbs to push up. } \\
\text { Session 4: Mat work - preparation for rolling in bed, pelvic movement, } 4 \text { point-kneeling with support. } \\
\text { Plans include } 2 \text { point kneeling, cycling on active/passive trainer, tilt-table and standing frame use in an attempt to } \\
\text { activate pelvic and lower limb muscles. }\end{array}$ \\
\hline
\end{tabular}


Table III: Clinical gains, in terms of muscle strength, in comparison to the patient's level of function at discharge from the rehabilitation facility, pre-operatively and 5 days post operatively

\begin{tabular}{|c|c|c|c|c|c|c|c|c|c|c|}
\hline \multirow{2}{*}{$\begin{array}{l}\text { Movement } \\
\text { Upper limbs }\end{array}$} & \multirow[t]{2}{*}{$\begin{array}{l}\text { Muscle group } \\
\text { (Muscles listed } \\
\text { cannot necessarily be } \\
\text { individually tested, } \\
\text { but have been graded } \\
\text { according to function) }\end{array}$} & \multirow[t]{2}{*}{$\begin{array}{l}\text { Nerve } \\
\text { supply }\end{array}$} & \multicolumn{2}{|c|}{$\begin{array}{l}\text { At discharge } \\
\text { from } \\
\text { rehabilitation } \\
\text { facility }\end{array}$} & \multicolumn{2}{|c|}{$\begin{array}{l}\text { Directly pre- } \\
\text { operatively } \\
\text { before AHESC } \\
\text { transplant } \\
\text { (neurosurgeon) }\end{array}$} & \multicolumn{2}{|c|}{$\begin{array}{l}\text { One week } \\
\text { after AHESC } \\
\text { transplant } \\
\text { (independent } \\
\text { neurosurgeon) }\end{array}$} & \multicolumn{2}{|c|}{$\begin{array}{l}\text { I2 Months } \\
\text { after AHESC } \\
\text { transplant }\end{array}$} \\
\hline & & & Right & Left & Right & Left & Right & Left & Right & Left \\
\hline $\begin{array}{l}\text { Scapular } \\
\text { abduction/ } \\
\text { upward rotation }\end{array}$ & Serratus Anterior & $\mathrm{C} 5-\mathrm{C7}$ & NT & NT & NT & NT & NT & NT & $2+$ & $2-$ \\
\hline Scapular elevation & $\begin{array}{l}\text { Upper trapezius/ } \\
\text { Levator scapulae }\end{array}$ & C3-5 & NT & NT & NT & NT & NT & NT & 4 & 3 \\
\hline $\begin{array}{l}\text { Scapular } \\
\text { adduction }\end{array}$ & Middle trapezius & $\mathrm{C5}$ & NT & NT & NT & NT & NT & NT & 3 & $2-$ \\
\hline $\begin{array}{l}\text { Scapular } \\
\text { depression/ } \\
\text { adduction }\end{array}$ & Lower trapezius & $\begin{array}{c}\text { XI } \\
\text { Accessory }\end{array}$ & NT & NT & NT & NT & NT & NT & $2+$ & $2-$ \\
\hline $\begin{array}{l}\text { Scapular } \\
\text { adduction/ } \\
\text { downward } \\
\text { rotation }\end{array}$ & Rhomboids & $\mathrm{C5}$ & NT & NT & NT & NT & NT & NT & $3+$ & $2+$ \\
\hline Shoulder flexion & $\begin{array}{l}\text { Ant Deltoid } \\
\text { Supraspinatus } \\
\text { Coracobrachialis }\end{array}$ & C5-7 & NT & NT & NT & NT & NT & NT & $2+$ & 1 \\
\hline $\begin{array}{l}\text { Shoulder } \\
\text { extension }\end{array}$ & $\begin{array}{l}\text { Latissimus dorsi } \\
\text { Teres major } \\
\text { Post Deltoid }\end{array}$ & C5-8 & NT & NT & NT & NT & NT & NT & $2+$ & 1 \\
\hline $\begin{array}{l}\text { Shoulder } \\
\text { abduction }\end{array}$ & $\begin{array}{l}\text { Middle Deltoid } \\
\text { Supraspinatus }\end{array}$ & C5-6 & 0 & 0 & 0 & 2 & 0 & 2 & $3+/ 4$ & $2-$ \\
\hline $\begin{array}{l}\text { Shoulder } \\
\text { horizontal } \\
\text { abduction }\end{array}$ & Posterior Deltoid & C5-6 & NT & NT & NT & NT & NT & NT & $2+/ 3$ & 1 \\
\hline $\begin{array}{l}\text { Shoulder } \\
\text { horizontal } \\
\text { adduction }\end{array}$ & Pectoralis Major & C5-TI & 0 & 0 & 0 & 0 & 0 & 0 & $2+$ & $2-$ \\
\hline $\begin{array}{l}\text { Shoulder external } \\
\text { rotation }\end{array}$ & $\begin{array}{l}\text { Infraspinatus } \\
\text { Teres minor }\end{array}$ & $\mathrm{C} 5-\mathrm{C} 6$ & 1 & 0 & 0 & 0 & 0 & 0 & $3+$ & $2-$ \\
\hline $\begin{array}{l}\text { Shoulder internal } \\
\text { rotation }\end{array}$ & Subscapularis & C5-TI & 0 & 0 & 0 & 0 & 0 & 0 & $2+/ 3$ & $2-$ \\
\hline Elbow flexion & $\begin{array}{l}\text { Biceps } \\
\text { Bracialis } \\
\text { Brachioradialis }\end{array}$ & $\mathrm{C} 5-\mathrm{C} 6$ & 1 & 0 & $3-$ & 0 & 3 & 0 & $4+$ & $1 / 2$ \\
\hline Elbow extension & Triceps & C7-C8 & 0 & 0 & 0 & 0 & 0 & 0 & $3+/ 4$ & $2+$ \\
\hline $\begin{array}{l}\text { Forearm } \\
\text { supination }\end{array}$ & $\begin{array}{l}\text { Supinator } \\
\text { Biceps }\end{array}$ & $\mathrm{C} 5-\mathrm{C} 6$ & NT & NT & NT & NT & NT & NT & $3+$ & $2-$ \\
\hline $\begin{array}{l}\text { Forearm } \\
\text { pronation }\end{array}$ & $\begin{array}{l}\text { Pronator teres } \\
\text { Pronator quadratus }\end{array}$ & $\mathrm{C} 6-\mathrm{C} 8$ & NT & NT & NT & NT & NT & NT & $3+/ 4$ & 1 \\
\hline Wrist flexion & $\begin{array}{l}\text { Flexor carpi radialis } \\
\text { Flexor carpi ulnaris }\end{array}$ & C6-TI & 0 & 0 & 0 & 0 & 0 & 0 & $1 / 2-$ & 0 \\
\hline Wrist extension & $\begin{array}{l}\text { Extensor carpi radialis } \\
\text { longus } \\
\text { Extensor carpi radialis } \\
\text { brevis } \\
\text { Extensor carpi ulnaris }\end{array}$ & $\mathrm{C} 5-\mathrm{C} 8$ & 0 & 0 & 0 & 0 & 0 & 0 & $1 / 2-$ & 0 \\
\hline Finger flexion & $\begin{array}{l}\text { Muscles not individually } \\
\text { assessed }\end{array}$ & C7-TI & 0 & 0 & 0 & 0 & 0 & 0 & 1 & 0 \\
\hline Finger extension & $\begin{array}{l}\text { Muscles not individually } \\
\text { assessed }\end{array}$ & $\mathrm{C6}-\mathrm{C} 8$ & 0 & 0 & 0 & 0 & 0 & 0 & 1 & 0 \\
\hline
\end{tabular}


. Table III continued from page 35

\begin{tabular}{|c|c|c|c|c|c|c|c|c|c|c|}
\hline \multicolumn{11}{|l|}{ Trunk } \\
\hline Extension & $\begin{array}{l}\text { Iliocostalis thoracis } \\
\text { Iliocostalis lumborum } \\
\text { Longissimus thoracis } \\
\text { Spinalis thoracis } \\
\text { Semispinalis thoracis } \\
\text { Multifidus } \\
\text { Rotatores thoracis/ } \\
\text { lumborum }\end{array}$ & TI-L4 & NT & NT & NT & NT & NT & NT & $2+$ & $2+$ \\
\hline Pelvis elevation & Quadratus lumborum & TI2-L3 & NT & NT & NT & NT & NT & NT & $2-$ & $2-$ \\
\hline Trunk flexion & Rectus abdominus & T7-TI2 & 0 & 0 & 0 & 0 & 0 & 0 & $2+/ 3$ & $2+/ 3$ \\
\hline Trunk rotation & $\begin{array}{l}\text { Obliquus externus } \\
\text { abdominus } \\
\text { Obliquus internus } \\
\text { abdominus }\end{array}$ & T7-LI & NT & NT & NT & NT & NT & NT & 2 & $2-$ \\
\hline \multicolumn{11}{|l|}{ Lower limbs } \\
\hline Hip flexion & $\begin{array}{l}\text { Psoas major } \\
\text { lliacus } \\
\text { Sartorius }\end{array}$ & L2-L4 & 0 & 0 & 0 & 0 & 0 & 0 & 0 & 0 \\
\hline Hip extension & $\begin{array}{l}\text { Gluteus maximus } \\
\text { Hamstrings }\end{array}$ & L5-S3 & 0 & 0 & 0 & 0 & 0 & 0 & 0 & 0 \\
\hline Hip abduction & $\begin{array}{l}\text { Gluteus medius } \\
\text { Gluteus minimus }\end{array}$ & L4-SI & 0 & 0 & 0 & 0 & 0 & 0 & 0 & 0 \\
\hline
\end{tabular}

the group home. He also expressed the desire to be more skilled with wheelchair use, so that he would no longer be restricted to areas where floor surfaces were smooth and even.

Rehabilitation tasks during Phase 3 (week 4I - 56) focused on enabling him to achieve these goals, while continuing to work on underlying components.

A detailed description of each phase of rehabilitation is provided in Table II on page 34.

\section{Quantitative Outcomes}

Louis was initially classified as ASIA A (no sensory or motor function is preserved in the sacral segments S4-S5). After 12 months, he had improved from ASIA A to ASIA C. (Motor incomplete: Motor function is preserved below the neurological level and more than half of key muscle functions below the single neurological level of injury (NLI) have a muscle grade less than 3.)

Sensation had improved from 25\% (ASIA 29/II4) to $60 \%$ (ASIA 69/II4). His sensation had improved to the extent that he was aware of light touch, and in particular deep pressure in all dermatomes and he was consistently accurate in localisation of touch above and up to LI. Below LI, localisation and speed of registration was impaired. At the time of writing an awareness of pain and temperature discrimination was developing.

He reported a proprioceptive awareness of muscles in his lower limbs with stretching, passive movement and weight bearing. He described sensations of burning, trembling, 'crawling underneath the skin' and 'electrical surges' and localised these sensations accurately. Louis had no prior anatomical knowledge, but accurately identified contraction of muscles during movement, increasing the veracity of his subjective report.

Over the course of twelve months, clinical gains in motor function, detailed in Table III, were made in the upper limbs, with muscle strength ranging from I to 4+ on the standard Oxford muscle grade system. Activation of all major muscle groups of the right upper limb was seen. Activity was less prominent in the left upper limb. During the transplant surgery nerve roots were found to have separated from the spinal cord. This may have been a reason for the slower recovery of the left upper limb. Twelve months after the transplant, electromyography showed that there was normal nerve conduction in the left upper limb.

In-hand movement and finger function was still limited to flick- ers of movement in the right hand only. However after twelve months, he had sufficient wrist and forearm movement to feed himself using a universal cuff, open and close his bedroom door independently, operate the light switch in his room, pull his water bottle towards himself, and perform some functions on a laptop computer.

Louis was able to sit unsupported. He had adequate trunk control to lean forwards, backwards and sideways, and was starting to use the trunk muscles functionally to participate actively in bed mobility and pressure relief. Because it was not possible to isolate individual trunk muscles when assessing muscle strength, we made use of his participation in real-life activities to grade the various muscle groups. Motor function was noted in thoracic, abdominal and spinal muscles with muscle strength range from I to $3+$ on the Oxford scale. Flickers of movement were also noted in gluteus medius.

Pre-transplantation investigations of cardiac and respiratory function had been done to determine Louis' fitness to withstand an extended period of anaesthesia. Although sufficiently fit to have the surgery, he still demonstrated classical respiratory restrictions associated with spinal cord injury and had limited cardiovascular endurance.

Despite the pre-transplantation findings of reduced total lung capacity and expiratory volume, he made significant improvements in endurance. At the start of rehabilitation, he was able to sit in his wheelchair for 6 hours at a time and although he participated in 60-minute rehabilitation sessions 4 times/day; active, minimally strenuous activity was initially only required for $50 \%$ of that time. Louis struggled with hypotension and thermal regulation and fatigued after about 30-45 minutes. After 12 months he was able to engage in rehabilitation for up to 180 minutes at a time and remained in his chair for 10 hours/day. He no longer has difficulty with hypotension and thermal regulation had improved significantly.

Independence in areas of bed-mobility, self-care, wheelchair mobility and participation in other activities continued to improve and are described in Table IV on page 37.

As stated, the Loewenstein Spinal Cord Independence Measure (SCIM-III) was used to measure gains in independence ${ }^{32}$. Louis' score on the SCIM improved from 12/100 pre-operatively to 
Table IV: Functional gains after 12 months

\begin{tabular}{|c|c|c|c|}
\hline \multicolumn{2}{|c|}{ Functional status pre-operatively } & \multicolumn{2}{|c|}{ Functional gains after 12 months } \\
\hline Bed Mobility & $\begin{array}{l}\text { Fully dependent. } \\
\text { No attempt at assisting carers. }\end{array}$ & Bed Mobility & $\begin{array}{l}\text { Able to assist carers when rolling from supine to side- } \\
\text { lying. } \\
\text { Able to roll back from side-lying to supine. } \\
\text { Active contraction of abdominal muscles when moving } \\
\text { from supine to long sitting reduces carer strain. }\end{array}$ \\
\hline Toileting & Fully dependent. & Toileting & $\begin{array}{l}\text { Sensory return of bladder aids patient to identify if } \\
\text { catheter has been correctly inserted and provides } \\
\text { feedback to carers. }\end{array}$ \\
\hline Transfers & $\begin{array}{l}\text { Fully dependent. } \\
\text { Only able to sit in semi-reclining } \\
\text { position in wheelchair with } \\
\text { external side-supports and head- } \\
\text { rest. }\end{array}$ & Transfers & $\begin{array}{l}\text { Remains fully dependent for transfers. } \\
\text { Able to sit unsupported in normal upright chair once } \\
\text { transferred. } \\
\text { Able to sit unsupported with supervision on static } \\
\text { surface without backrest. }\end{array}$ \\
\hline Personal Hygiene & Fully dependent & Personal hygiene & Remains fully dependent. \\
\hline Feeding and Drinking & Fully dependent & Feeding and drinking & $\begin{array}{l}\text { Able to use spoon for feeding with universal cuff but } \\
\text { dependent on set-up. } \\
\text { Able to reposition drinking bottle for easy access by } \\
\text { pulling towards self or pushing away. } \\
\text { Able to hold bottle provided by carer against torso to } \\
\text { drink. }\end{array}$ \\
\hline Wheelchair use & $\begin{array}{l}\text { Required head-rest and side } \\
\text { supports. } \\
\text { Manipulates joystick control by } \\
\text { using shoulder movement. } \\
\text { Unable to counter muscle spasms } \\
\text { - occasional falls from chair. } \\
\text { Unable to identify correct position } \\
\text { in chair. Dependent on carer skill } \\
\text { for positioning. } \\
\text { Semi-reclined in seat. } \\
\text { Unable to maintain upright } \\
\text { posture without external support. } \\
\text { Unable to move in chair to assist } \\
\text { carers. } \\
\text { Unable to exit from vehicle } \\
\text { without carer assistance as unable } \\
\text { to maintain upright posture } \\
\text { against gravity. }\end{array}$ & Wheelchair use & $\begin{array}{l}\text { No longer requires head-rest or side supports. } \\
\text { Manipulates joystick control by using wrist and forearm } \\
\text { movement. } \\
\text { Able to counter muscle spasms and prevent falling out } \\
\text { of chair. } \\
\text { Able to identify need for re-positioning in chair and give } \\
\text { instructions. } \\
\text { Angle of seat has been adjusted to allow for more } \\
\text { upright posture. } \\
\text { Able to maintain upright posture without use of side- } \\
\text { supports. } \\
\text { Able to lean forward in chair to allow carers to adjust } \\
\text { clothing. } \\
\text { Able to lean over side of chair to inspect wheels and } \\
\text { brakes and return to upright position. } \\
\text { Able to exit from vehicle independently without } \\
\text { assistance from carer. }\end{array}$ \\
\hline Recreational activities & Fully dependent & Recreational activities & $\begin{array}{l}\text { Able to skip songs on mobile phone. } \\
\text { Able to remove headphones. } \\
\text { Able to use touch pad and mouse buttons on laptop } \\
\text { computer. }\end{array}$ \\
\hline Other & $\begin{array}{l}\text { Decreased confidence as } \\
\text { dependent on carers for safety. } \\
\text { Unable to perform any functional } \\
\text { tasks apart from wheelchair } \\
\text { control. } \\
\text { No awareness of human touch, } \\
\text { unable to respond appropriately. } \\
\text { No possibility of improving degree } \\
\text { of functional independence. }\end{array}$ & Other & $\begin{array}{l}\text { Improved confidence with regard to falls from bed and } \\
\text { chair as able to maintain upright posture. } \\
\text { Improved ability to use upper limb for functional } \\
\text { activities while retaining balance. } \\
\text { Awareness of human touch and able to respond to non- } \\
\text { verbal communication of carers. } \\
\text { Increasing self-belief in ability to achieve greater degree } \\
\text { of functional independence. }\end{array}$ \\
\hline
\end{tabular}

24/100 after 12 months, with improvement in feeding, grooming, sphincter management and bed mobility.

\section{Qualitative outcomes}

Although the changes described above are academically significant, it could be argued that there has not been much objectively measured improvement in his independence in participation in activities of daily living. This raises the question of whether the surgical intervention and subsequent rehabilitation have made a meaningful impact on Louis' quality of life.

The responses shown in Table $V$ on pages 38/39 illustrate the profound impact that this process has had on him and his family.

Although Louis' initial perception of the purpose of rehabili- tation was to achieve increased physical independence, it soon became clear, that it was also becoming a journey to re-create himself. This is illustrated by recurring themes in his responses which include: having a new purpose, feeling less disabled, having greater self-confidence and improved self-esteem, having greater physical and emotional freedom, being more productive and having improved psychological well-being. His responses can perhaps best be interpreted using the model of Creative Ability $^{49}$. The theory of Creative Ability states that there are three components that are interdependent and required for personal growth. Firstly, creative response, or having a positive attitude towards an opportunity, despite anxieties regarding capability or outcome. For Louis, this statement illustrates this first component 
best: I dreamed about the day I would get treatment and I promised God that whatever the outcome, I would fight to the bitter end... Secondly, creative participation, or the active participation in activities which challenge our capabilities. He says: Every inch of movement and every tickle of sensation that I get are what drives me to push harder and harder. Lastly, the creative act - the tangible or intangible end product of the combination of the previous two components. In this case, it is best demonstrated in the changes in his observable behaviour. Previously, Louis avoided social interaction, as he was self-conscious and concerned about the effort others would have to go to, to enable him to attend social events or participate in activities. He tended to avoid conversa- tion and would not give his opinions freely. After 12 months of rehabilitation, he is confident in his own abilities, continuously attempts new tasks on his own, engages spontaneously with others about his experiences and is eager to act as an advocate for those who might wish to follow in his footsteps. Ultimately I hope that I will be able to walk again but even if that is not possible, the most important thing for me is to have some freedom back. I would like to make decisions about my own life again and help others make informed decisions about theirs.

The functional and emotional changes that have come about as a result of the transplant and rehabilitation clearly illustrate that the procedure and rehabilitation have been beneficial, both from

\section{Table V: Impact on Quality of Life questions and answers}

\section{How has your recovery changed your life?}

'The greatest change is the fact that I am way less bedridden than before. Struggling with pressure ulcers on both ankles for 7 years I was forced to stay in bed 3-4 days a week so that the swelling in my feet could subside. I now have virtually no muscle pain in my shoulders and neck on a daily basis anymore, as I had before the surgery. My lung capacity has also increased and I speak more fluently without feeling dizzy after lengthy conversations. Before I started exercising I was sleepy most of my day and it felt like I had little energy and I struggled to concentrate on something for more than I0 minutes. Now my energy levels are up and I actually look forward to my daily activities with a positive spirit. Every inch of recovery I have had so far has given me more hope and it has completely altered my psychological state of mind for the better...I can open and close my room door now, which is a first step towards independence and my first form of privacy in 8 years. To have independence is to have freedom from my bodily prison.'

\section{How has the recovery changed your life goals?}

'Before my surgery I had no ambition or dreams to do something with my life. I was literally waiting on death because the severity of my disability was such that I couldn't see myself function in society. I could hardly operate my motorised wheelchair so what could I possibly do... It felt as if I had no purpose in life and therefore I had no dreams, goals or ideals. I had become cold towards life in many aspects. My religion suffered a great deal, my outlook on love and relationships had changed so much...Life had become my own private hell.

Post-surgery and a few months into rehabilitation my mind started to change. I could feel changes in my body and I began to set small goals for myself and by reaching them I became more positive about my life and my purpose on this earth. Now a lot of my dreams have become goals, and just before I have reached them, I have even had the courage to set the goalposts further, which was a major step in my life...my dreams, goals and aspirations are slowly coming back into my frame of mind.'

\section{How has your recovery impacted your participation in activities of daily living?}

'Before I started going to rehabilitation every day, my days and weeks were pretty monotonous. Mind-numbing routine.

Nowadays it feels as if I'm productive. I am picked up early in the morning, I have my breakfast and I am driven to rehab for the day. The fact that I'm getting out of the house on a daily basis did wonders for my psychological well-being. Being more positive I would try to do small things myself whereas in the past I would need someone to help me. Things like opening and closing my door, moving my water bottle so that I can drink, scratching my face and even operating my cell phone when placed on my lap.'

\section{How has your recovery impacted on your family?}

I would say it would have had an impact on their lives (dad, mom , sister) because I think it's important for family members to know, to feel and to see that I'm happy under the circumstances that I'm in. I think the gist of it is that my family are happy when they see that I'm happy.

I constantly run into friends and family friends who I haven't seen for a while and they would always tell me how well I look. I don't always know what that means but I have been told before that my eyes are shining again!'

\section{Has your recovery had a financial impact on your life in terms of day-to-day costs?}

'Yes my recovery has had a financial impact on my current day-to-day living cost, but let me explain. I don't think that people understand what sort of financial impact disability has on people. People think you buy a wheelchair and you sit in it, and that is about your only expense. For every problem that a disabled person might encounter there are aids available at a steep price of course. If you can't afford these devices, medicines, plasters etc. it could most certainly lead to a heavy decline in one's health and would almost certainly lead to death. So the point that I'm trying to make is that in the first place, disability has probably more than doubled my cost of living. Secondly, yes my rehab has had a direct impact on my day-to-day expenses although the improvement of my physical state has already shown a decrease on my expenses for unforeseen medical necessities. In the long term I feel that the current extra expense on fuel and therapy shouldn't even be calculated as you cannot put a monetary value on happiness, well-being and health. In the long run I foresee no extra medical expenses due to a more healthy body and that alone would justify the little extra expenditure on recovery.'

\section{How has the improvement in sensation impacted your life?}

'Before I had absolutely no sense of sensation except for 4 fingers above my nipple line and up. This was the cause of pressure sores, red spots etc on my bum, legs and ankles. The only indication I had was an uncomfortable sweat after a long period of time and then it was a guessing game as to what the problem really was. About 8 months after surgery I had begun to become aware of stimuli instantly and at random all over my body. While sleeping at night I would regularly awake after I had a spasm and my ankle (with pressure ulcer) would move onto the pillow. Within a couple of minutes I would start to perspire and I would call for a carer and as soon as my ankle was taken off the pillow the sweating would cease. All over my body sensation is slowly returning and this seems to also have an effect on my sensitivity for temperature, where pre-surgery I would easily be over sensitive for cold and once cold it would take ages to warm up. Even so with heat. When sitting in the sun I would overheat and realise it too late. I would be in and out of consciousness and it took quite some effort to bring my temperature down. Post-surgery l'm less sensitive to cold and more temperature aware when out in the sun. I am able to identify when my body heat is going too high and when to get out of the sun. My sensory improvement has given me $a$ sense of security in situations where temperature is involved as I can better rely on my own judgement. 


\section{How has the improvement in motor function impacted your life?}

'It has had quite a significant impact if not the most important as to yet. It is also the function of my body that needs the most work. After the operation I had less function in my right arm and still no function in the left. Within a few weeks my right arm was back on track and work had begun to strengthen $i t$. The general strength of the arm is light years ahead of where it used to be and this has brought a bit of quality to my life. I handle my chair with ease now and don't bang into everything all the time. I am able to open and close my door, scratch my head and face and operate my cell phone to a certain extent. The most amazing thing in my opinion are the postural muscles coming to life. Being able to sit on my own once I have found my balance point, and move front to back and side to side is an incredible feeling and psychological boost. Having some strength in these muscles helps me to keep myself in an upright position when I'm in my wheelchair and also gives confidence to venture a bit further with my motorised chair, a sense of 'freedom' I haven't felt in many years. I feel more confident about myself and my image and having this improvement in a sense makes me feel 'less disabled'. I don't care anymore how people stare at me or perceive me."

\section{How has your recovery impacted your bowel and bladder function?}

'More or less a year after the operation I started noticing different sensation with regards to my bladder. The first thing that I had noticed was when changing a catheter, the uncomfortable feeling I felt when the old catheter was being removed and pulled past the sphincter muscle. Something I haven't experienced before. At first the hair on my arms and neck would stand up and a few seconds afterwards I would feel a dull throbbing in the bladder area. Once the new catheter is inserted correctly it would take a good few minutes for the 'pain' (uncomfortableness) to go away. Another thing that I have noticed is that at times when the sphincter is in spasm when trying to insert the catheter, and the carers has mistakenly blown up the bubble inside the urethra, I pick up the pressure within a couple of seconds. This is a huge bonus because it has saved me from a lot of agony. When my leg bag fills up and pressure starts to build up I also notice it way before the time, whereas in the past I would eventually begin to sweat and only visually notice my ful urine bag. My bowel function has almost stayed the same except for the fact that it feels like the moment passes quicker with less hassle."

\section{How has your recovery changed how you use your free time and what choices you make about leisure activities?}

'I can't say that I think differently about what I do in my free time. What I can say though is that I do consider, and do things, that I would've never done in the past. Like the side-car adventure for instance. The physical improvement has given me more confidence in social situations...I feel more confident, more secure and I think about doing things now that I would never have considered before the surgery.'

\section{How has your recovery impacted your participation in work activities?}

'My studies have suddenly become important to me, because I have hope now and an ideal would be to go back to work one day, and even if I don't I would like to graduate purely for self-fulfilment. I am able to do more hours but I have to be motivated.

I am studying with more self-motivation than before as I feel that my studies might actually be worthwhile now. For the first time since my accident, I can think about the possibility of working again, as this might now be a reality.

I am healthier now, meaning that there are more days per month that I can study and work. Before the surgery, I was up and about and actively involved in life, maybe $30 \%$ of the time. Now, staying in bed feels like a waste of time. I want to be involved in life now.'

\section{How has your recovery been most significant to you?}

'I have always known that I would have stem cells implanted because doing nothing about my situation was never an option. So I dreamed about the day I would get treatment and I promised God that whatever the outcome, I would fight to the bitter end, He just had to give me that chance to prove myself. I would fight for any and every inch of improvement possible... now I had gotten just what I asked for. A chance of a lifetime had fallen in my lap, the only chance of regaining my life. So how has my recovery been significant to me? It is what I live for. There is hope again. Without hope in my life I have nothing. Every inch of movement and every tickle of sensation that I get are what drives me to push harder and harder. The huge, yet little improvement that I have made so far has altered my life in so many ways. I feel alive again.'

\section{What do you hope for in the future?}

"For in hope we have been saved, but hope that is seen is not hope; for who hopes for what he already sees? But if we hope for what we do not see, with perseverance we wait eagerly for it." Romans 8:24-25

'Years ago when my doctors told me there was no hope I bluntly refused to believe it. I dreamed about the impossible, that I would one day walk again. My dream became my belief and through believing in my dream I had hope for my future.

Eight years ago, the doctors told me that maybe in 10 years there will be a cure...today patients are still being told in that there might be $a$ cure 10 years from now... but if no one is willing to do anything to make that happen, is that not giving them false hope?

I hope that what we are doing is not in vain, that there will be other brave souls who will be willing to take a risk.

Ultimately I hope that I will be able to walk again but even if that is not possible, the most important thing for me is to have some freedom back. I would like to make decisions about my own life again and help others make informed decisions about theirs.'

a physical and functional point of view, but perhaps even more importantly from a personal, social and emotional perspective.

\section{DISCUSSION}

In South Africa, as in many parts of the world, the focus of clinicians in $\mathrm{SCl}$ rehabilitation is on assisting patients to achieve sufficient physical independence to enable safe discharge to a community setting. This is a good and true goal, and Occupational therapy has always been an essential part of this kind of $\mathrm{SCl}$ rehabilitation. Occupational Therapists aim to maximise independence, and facilitate a return to productive and fulfilling participation in life, but in the authors' experience, the challenges presented to the implementation of hospital and community based rehabilitation, particularly in South Africa, means that most patients' rehabilitation journey ends three to four months after their injury. They may have achieved sufficient physical independence to be discharged, but their participation and quality of life has often not been maximised.

For patients with complete $\mathrm{SCl}$, the perception has been that this is acceptable, as no further recovery is anticipated, but the advent of regenerative medicine may force us to reconsider our approach.

If a patient has the resources and internal drive to seek alternative treatment, and even a glimmer of hope for improvement exists, are we equipped to deal with the rehabilitation challenges that this could present?

In Louis' case, rehabilitation commenced at a stage when therapy would ordinarily have been discontinued long ago, and the degree of impairment was constantly changing.

The rehabilitation approach used had several notable strengths. It was designed after a review of available literature from a variety of fields, and incorporated many aspects of the interdisciplinary team 
approach. It provided a framework within which the emergence of new neurological function could be accurately and rapidly identified and therapy tailored accordingly. A variety of treatment strategies from three rehabilitation professions were used to achieve the best possible quantitative and qualitative outcomes for the patient. Rehabilitation was characterised by persistence and endurance on the part of the therapists and the patient, and demanded creative thinking and innovation.

Critics have suggested that the transplantation of stem cells was irrelevant to the gains in sensory and motor function and independence that our patient achieved, and that the intensity of rehabilitation alone would have achieved the same result. Literature would seem to indicate that this is not the case ${ }^{24,25}$. In the study by Lima et $a l^{25}$, patients received four months of pre-transplant rehabilitation, which made no difference. In the study by Tabakow et $a l^{26}$, their patient received three months of daily rehabilitation prior to his transplant, and also demonstrated no functional change. What remains unclear is whether patients would improve solely as a result of receiving cell-based interventions and no rehabilitation. Are the cells the magic bullets, or is a combination approach of cells and rehabilitation essential?

It seems that it is not possible to dissociate the effect of the rehabilitation from the preceding transplant procedure. Clinical trials would be required to gather evidence regarding the impact of the different variables, in order to gather strong evidence to change practice and facilitate patient selection for future procedures. For example, the impact of glial scar resection on recovery is not known. Would transplantation without scar resection have had similar outcomes? The open surgical technique which is required for the implantation of stem cells implies that only patients with very particular lesions could be considered for surgery. Randomisation for this particular procedure would therefore, in our opinion, not be possible.

Comparative studies on the rehabilitation outcomes in patients who receive rehabilitation before and after regenerative therapy, is recommended as a way of establishing the efficacy of such treatments. Randomised controlled trials should also be considered in patients who have received regenerative treatments, to establish which rehabilitation techniques and schedules are most effective. Variables which could influence the outcome of rehabilitation would have to be taken into account when developing research protocols. These could include the types of stem cells used, the type of procedure utilised, length of time lapsed since injury and a multitude of other health and contextual factors. Co-morbid conditions, pre-existing secondary complications, age, education, access to transport, internal drive, and mental health, would all have to be considered.

As the field of regenerative medicine progresses it is likely that more patients will require rehabilitation following chronic and static disability, and that the need for innovative and pragmatic approaches to deliver such intensive therapy will continue to increase. Furthermore, our report highlights the need for the design of specific outcome measures to quantify physiological and anatomical recovery. In a field in which controversy abounds and claims of miraculous improvement are frequently made, it is essential to have as much objective evidence of change as possible. As can be clearly seen from the changes that our patient experienced and the perceived impact of these changes on his health and well-being, qualitative research could also add value to our understanding of this area of rehabilitation. The marked impact on this particular patient's self-confidence, mood, self-esteem, and perspectives on life, that have been brought about by his participation in rehabilitation and the subsequent functional gains, highlights the importance of never giving up hope.

In our opinion, the promise of even minimal recovery for a patient population who would previously have had no hope, demands the investigation of methods to make treatment and rehabilitation readily available. Further research into the most effective rehabilitation approach, intervention schedules and accurate measurement of improvement is essential.

\section{CONCLUSION}

We describe an integrated, inter-disciplinary programme of rehabilitation in a chronic cervical SCl patient. Over the course of a I2-month period, the patient received approximately I7 hours of interdisciplinary therapy per week, and progressed from ASIA A to ASIA C. Sensation improved to the extent that the patient is aware of light touch, pain and pressure and localisation was accurate to the level of LI. Motor function had improved in both upper limbs and trunk, enabling active participation in personal hygiene activities, improved wheelchair mobility and increased participation in leisure and work tasks. Our findings provide evidence of the value of rehabilitation in this setting, and show that considerable gains in functional capacity, improved psychological well-being and quality of life are achievable.

To our knowledge, this is the first report of a rehabilitation programme in the setting of AHESC in South Africa. Although there are numerous reports on the treatment of patients with chronic $\mathrm{SCl}$ with cell-based therapies, literature that comprehensively describes both the rehabilitation intervention and subsequent quality of life changes in such cases is very limited. Most reports focus on the anatomical and physiological changes as outcomes, and although these are essential and clinically significant, it is the improvement in quality of life, participation, well-being, general health and perception of self which is exciting for this population.

Our report demonstrates the physical, functional and qualityof-life changes which occurred over a period of 12 months, and highlights the functional, social and emotional changes that were observed. No negative symptoms or adverse effects were identified or experienced by the patient at the time of writing. He continues to receive rehabilitation on a daily basis and continues to improve.

\section{ACKNOWLEDGMENTS}

The authors would like to thank DrWA Liebenberg, Neurosurgeon.

\section{REFERENCES}

I. Lali HS, Felings, MG. Epidemiology, Demographics and Pathophysiology of Acute Spinal Cord Injury. Spine, 26, 24S: S2 - SI 2.

2. Cristante AF, de Barros Filho TEP, Marcon RM, Letaif OB, da Rocha, ID. Therapeutic Approaches for spinal cord injury. Clinics, 2012; 67(10): 1219-1224.

3. Towards a Common Language for Functioning, Disability and Health ICF. http://www.who.int/classifications/icf/training/icfbeginnersguide.pdf.

4. Lim, Peter AC, Tow, Adela M. Recovery and Regeneration after Spinal Cord Injury: A Review and Summary of Recent Literature. Annals Academy of Medicine Singapore, 2007; 36(I): 49-57.

5. Ditunno JF, Formal CS. Current Concepts: Chronic Spinal Cord Injury. New England Journal of Medicine, Feb. 24, 1994: 550 556 [http://dx.doi.org/10.1056/NEJMI99402243300808] [PMID: 8302323].

6. Donnelly C, Eng JJ, Hall J, Alford L, Giachino R, Norton K, Kerr GS. Client-centered assessment and the identification of meaningful treatment goals for individuals with a spinal cord injury. Spinal Cord, 2004; 42: 302-307. [http://dx.doi.org/10.1038/sj.sc.3101589] [PMID: 14993893].

7. McDonald JW, Becker D, Sadowsky CL, Jane JA, Conturo TE, Schultz LM. Late Recovery following spinal cord injury. Journal of Neurosurgery, (Spine 2) 2002; (97): 252-265.

8. Ntale A, Taylor S, LaBarbera J, Bensimon L, McDowell S, Mumma SL, Backus D, Zanca JM, Gassaway J. Classification of SCI Rehabilitation Treatments SCIRehab Project Series: The Physical Therapy Taxonomy. Journal of Spinal Cord Medicine, 2009 June, Vol 32 (3): $270-282$.

9. Ozelie R, Sipple C, Foy T, Cantoni K, Kellogg K, Lookingbill J, Backus $\mathrm{D}$, Gassaway J. Classification of SCI Rehabilitation Treatments SClRehab Project Series: The Occupational Therapy Taxonomy. Journal 
of Spinal Cord Medicine, 2009 June, Vol 32 (3), 2009: 283 -296.

10. Burns AS, Ditunno JF. Establishing Prognosis and Maximising Functional Outcomes after Spinal Cord Injury. Spine, 200I; December 15, Vol 26, 24S: SI37-SI45.

II. Ditunno JF, Formal CS. Current Concepts Chronic Spinal Cord Injury. New England Journal of Medicine, Feb 24, 1994: 550-556.

12. Consortium for Spinal Cord Medicine. Early Acute Management in Adults with Spinal Cord Injury: A Clinical Practice Guideline for Healthcare Professionals. Journal of Spinal Cord Medicine, 2008; 3 I (4) 403-497 [PMID: I8959359].

13. Marcel WM, Dallmeijer AJ, Angenot ELD, van Asbeck FWA, van der Woude LHV. Duration and functional outcome of spinal cord injury rehabilitation in the Netherlands. Journal of Rehabilitation Research and Development, 2005 May/June, Vol 42 (3): 75 - 86.

14. Du Toit, D.F. \& Liebenberg, W.A., 2014. Embryonic Intra-spinal Stem Cell Transplant in a Chronic Complete Quadriplegic Patient. Neuro-anatomical Outcome after One Year. Revista Argentina de Anatomia Clinica, 6(I), pp.35-42.

I5. Tooth L, McKenna, K, Geraghty, T. Rehabilitation outcomes in traumatic spinal cord injury in Australia: functional status, length of stay and discharge setting. Spinal Cord, 2003; (4I): 220-230.

16. http://www.medicalschemes.com/medical_schemes_pmb/conditions covered.htm (Accessed 3/2/2015)

17. Thuret S, Moon LDF, Gage FH. Therapeutic interventions after spinal cord injury. Nature. August 2006: Vol 7(8): $628-643$.

18. Tsuji O, Miura K, Okada Y, Fujiyoshi K, Mukaino M, Nagoshi N, Kitamura K, Kumagai G, Nishino M, Tomisato S, Higashi H, Nagai T, Katoh H, Kohda K, Matsuzaki Y, Yuzaki M, Ikeda E, Toyama Y, Nakamura M, Yamanaka S, Okano H. Therapeutic potential of appropriately evaluated safe-induced pluripotent stem cells for spinal cord injury. Proceedings of the National Academy of Sciences. 107 (28). July 20I0: I2704-12709.

19. Bartolomei JC, Greer CA. Olfactory Ensheathing Cells: Bridging the Gap in Spinal Cord Injury. Neurosurgery, November 2000; 47(5): 1057-1069

20. Park HC, Shim YS, Ha Y, Yoon SH, Park SR, Choi BH, Park HS. Treatment of Complete Spinal Cord Injury Patients by Autologous Bone Marrow Cell Transplantation and administration of GranulocyteMacrophage Colony Stimulating Factor. Tissue Engineering, I I, 5/6. 2005: 913-922.

2I. Jarocha D, Milczarek O, Kawecki Z, Wendrychowicz A, Kwaitkowski S, Majka, M. Preliminary study of autologous bone marrow nucleated cells transplantation in children with spinal cord injury. Stem cells translational medicine, 20I4; 3(3): 395-404.

22. Nemati S, Jabari R, Hajinahsrollah M, Zare Mehrjerdi N, Azizi $H$, Hemmesi K, Azhdhari Z, Telebi A, Mohitmafi S, Vosough Dizaj A, Sharifi G, Baharvand H, Kiani S, Rezaee O. Transplantation of Adult Monkey Neural Stem Cells into A Contusion Spinal Cord Injury Model in Rhesus Macaque Monkeys. Cell journal, 2013; 16(2): II7-130.

23. Lynskey JV, Belanger A, Jung R. Activity dependent plasticity in spinal cord injury. Journal of Rehabilitation Research and Development, 2008; 45 (2): 229-240.

24. Behrman AL, Bowden MG, Preeti MN. Neuroplasticity After Spinal Cord Injury and Training: An Emerging Paradigm Shift in Rehabilitation and Walking Recovery. Physical Therapy, 2006; 86: I 406-I 425.

25. Lima C, Escada P, Pratas-Vital J, Branco C, Arcangeli CA, Lazerri G, Santana Maia CA, Capucho C, Hasse-Ferreira A, Peduzzi JD. Olfactory Mucosal Autografts and Rehabilitation for Chronic Spinal Cord Injury. Neurorehabilitation and Neuronal Repair, 2010; Vol 24, (I): I- 22.

26. Tabakow P, Raisman G, Fortuna W, Czyz M, Huber J, Li D, Szewczyk P, Okurowski S, Miedzybrodzki R, Czapiga B, Salomon B, Halon A, Li Y, Lipiec J, Kulcziek A, Jarmundowicz W. Functional regeneration of supraspinal connections in a patient with transected spinal cord following transplantation of bulbar ofactory ensheathing cells with peripheral nerve bridging. CT- 1239 Cell Transplantation Early Epub, provisional acceptance 08/26/20I4.

27. Endo T, Spenger C, Tominaga T, Brene S, Olson L. Cortical sensory map rearrangement after spinal cord injury: f-MRI responses linked to Nogo signalling. Brain. 2007; I30: 295 I-296I.

28. Tabakow P, Jarmundowicz W, Czapiga B, Fortuna W, Miedzybrodzki R, Czyz M, Huber J, Szarek D, Okurowski S, Szewczyk P, Andrzej
Gorski A, Raisman G. Transplantation of autologous olfactory ensheathing cells in complete human spinal cord injury. Cell Transplantation, 2013; 22(9) I59-162.

29. www.spinalinjury 101 .org/details/asia-iscos. Understanding spinal cord injury. ASIA/ISCoS Exam and grade.(Accessed 25/9/20I2).

30. Landrum PK, Schmidt MD, MacLean A. Outcome-oriented Rehabilitation. Aspen Publishers Inc. Gaithersburg, Maryland, 1995.

3I. Hassan SAM, Visagie S, Mji G. The achievement of community integration and productive activity outcomes by CVA survivors in the Western Cape Metro Health District. South African Journal of Occupational Therapy. 2012: 42(I): II-I5.

32. Fekete C, Eriks-Hoogland I, Baumberger M, Catz A, Itzchovich M, Luthi H, Post MW, von Elm E, Wyss A, Brinkhoff MW. Development and validation of a self-report version of the Spinal Cord Independence Measure (SCIM III). Spinal Cord, 20 I 3: 5 I (I): 40-47.

33. Ferrans C E and Powers MJ. Quality of life index Spinal Cord Version. [http://www.commondataelements.ninds.nih.gov/Doc/NOC/ Quality of Life Index Spinal Cord Injury Version NOC Link. pdf] (Accessed 23/I/2013)

34. Rogers, C.R., 196I. On becoming a person. Boston: Houghton Miller Company.

35. Dickstein R, Deutsch JE. Motor Imagery in Physical Therapist Practice. Physical Therapy, 2007; 87: 942-953 [http://dx.doi.org/10.2522/ pti.2006033 I] [PMID: 17472948].

36. Jeannerod M, Decety J. Mental motor imagery: a window into the representational stages of action. Neurobiology, 1995; 5: 727732. [http://dx.doi.org/10.1016/0959-4388(95)80099-0] [PMID: 8805419].

37. Poole, JL. Application of Motor Learning Principles in Occupational Therapy. American Journal of Occupational Therapy, 1991; 45:6; 531-537. [http://dx.doi.org/10.5014/ajot.45.6.531] [PMID:2063942].

38. Ramachandran VS, Altschuler E. Review Article: The use of visual feedback, in particular mirror feedback, in restoring brain function. Brain, 2009; 132: 1693-1710. [http://dx.doi.org/10.1093/brain/ awpl35] [PMID: 1950607I].

39. Rizzolatti G, Fabbri-Destro M, Cattaneo L. Mirror neurons and their clinical relevance. Nature Clinical Practice: Neurology, 2009; 5 (I): 24-34. [http://dx.doi.org/10.1038/ncpneuro-0990] [PMID: 19129788].

40. Byl N, Roderick J, Mohammed O, Hanny M, Kotler J, Smith A, Tang M, Abrams G. Effectiveness of Sensory and Motor Rehabilitation of the Upper Limb Following the Principles of Neuroplasticity: Patients Stable Poststroke. Neurorehabilitation and Neural Repair. 2003; 17(3): 176 - 191.

4I. Dobkin BH. Rehabilitation after Stroke. New England Journal of Medicine. 352; 16:77-84

42. Barreca S, Wolf SL, Fasoli S, Bohannon R. Treatment Interventions for the Paretic Upper Limb of Stroke Survivors: A Critical Review. Neurorehabilitation and Neural Repair. 2003; 17(4): 220 - 226.

43. Yang JF, Musselman KE, Livingstone D, Brunton K, Hendricks G, Hill D, Gorassini M. Repetitive Mass Practice or Focused Precise Practice for Retraining Walking After Incomplete Spinal Cord Injury? A Pilot Randomised Clinical Trial. Neurorehabilitation and Neural Repair. 2014;28(4):314-324. [http://dx.doi. org/I0.1 I 77//5459683 I3508473] [PMID:242/3960].

44. Freund P, Weiskopf N, Ward NS, Hutton C, Gall A, Cicarelli O, Craggs M, Friston K, Thompson AJ. Disability, atrophy and cortical reorganisation following spinal cord injury. Brain, 201 I; 134: $1610-1622$.

45. Edgerton RV, de Leon RD, Harkema SJ, Hodgson JA, London N, Reikensmeyer DJ, Roy RR, Talmadge RJ, Tillakaratne NJ, Timoszyk W, Tobin A. Retraining the injured spinal cord. Journal of Physiology, 200I; 533.1 : I5 -22.

46. Freund P, Weiskopf N, Ashburner J, Wolf K, Sutter R, Altmann DR, Friston K, Thompson A, Kurt A. MRI investigation of the sensorimotor cortex and the corticospinal tract after acute spinal cord injury: a prospective longitudinal study. Lancet Neurology, 2013; I2(9): $873-88$ I.

47. Moseley GL, Flor H. Targeting Cortical Representations in the Treatment of Chronic Pain: A Review. Neurorehabilitation and Neural Repair, $X X(X)$ : I- 7.

48. Dubouloz CJ, Vallerand J, Laporte D, Ashe B, Hall M. Occupational 
performance modification and personal change among clients receiving rehabilitation service for rheumatoid arthritis. Australian Occupational Therapy Journal, 2008: 55, 30-38.

49. The Model of Creative Ability: [http://www.vula.uct.ac.za/access/ content/group/9c29ba04-blee-49b9-8c85-9a468b556ce2/Framework_2/pdf/The\%20Model\%20of\%20Creative\%20Ability.pdf (Accessed 3/2/2015)

\section{Corresponding Author}

\section{Linda Elizabeth Hiemstra}

Back2work Occupational Therapy

Office 20I, Second Floor, Tygerburg Centre

16 Voortrekker Rd, Bellville

Linda.Hiemstra25@gmail.com 